\title{
FAKTOR-FAKTOR YANG MEMPENGARUHI KEPUASAN DAN KEPUTUSAN BERTRANSAKSI NASABAH PENGGUNA MANDIRI SYARIAH MOBILE (MSM)
}

\author{
Anggit Pragusto Sumarsono ${ }^{1}$, Mhd Handika Surbakti ${ }^{2}$, Nurul Huda ${ }^{3}$ \& Nova Rini ${ }^{4}$ \\ ${ }^{1 \& 2}$ Universitas Indonesia \\ ${ }^{3}$ Universitas Yarsi \\ ${ }^{4}$ STIE Muhammadiyah Jakarta \\ Email :anggit.pragusto@ui.ac.id,mhd.handika@ui.ac.id,nurul.huda@yarsi.ac.id,
} nvrin207@yahoo.com

\begin{abstract}
ABSTRAK
Penelitian ini bertujuan untuk mengetahui faktor-faktor yang mempengaruhi kepuasan dan keputusan bertransaksi nasabah pengguna mobile banking pada Bank Syariah Mandiri (BSM). Penelitian ini adalah penelitian kuantitatif dengan pengolahan data menggunakan analisis deskriptif dan analisis structural equation model (SEM) pendekatan partial least square (PLS). Populasi dalam penelitian ini adalah nasabah BSM yang menggunakan Mandiri Syariah Mobile (MSM) dengan pemilihan sampel menggunakan convient sampling yang termasuk dalam teknik sampling non-probability sampling. Jenis data pada penelitian ini yaitu data primer yang diperoleh dari hasil pengisian kuesioner tanggapan responden. Hasil penelitian menunjukkan bahwa fitur transfer adalah fitur yang paling dibutuhkan oleh nasabah pengguna MSM, sedangan fitur religi adalah fitur yang paling tidak dibutuhkan. Tetapi uniknya tingkat kepuasan terhadap fitur religi tercatat paling tinggi dibandingkan dengan fitur-fitur lainnya. Didapatkan juga adanya pengaruh signifikan dari variabel efisiensi, kepercayaan (trust) dan keberkahan terhadap kepuasan nasabah pengguna MSM, sedangkan untuk variabel kemudahan tidak menunjukkan pengaruh yang signifikan. Kepuasan nasabah tersebut juga berpengaruh signifikan terhadap peningkatan keputusan nasabah dalam bertransaksi melalui MSM.
\end{abstract}

Kata kunci : Maslahah, Bank Syariah, Mobile Banking.

\begin{abstract}
This study aims to determine the factors that influence customer satisfaction and transaction decisions of mobile banking users at Bank Syariah Mandiri (BSM). This research is a quantitative research with data processing using descriptive analysis and structural equation modeling (SEM) partial least square (PLS) approach. The population in this study were BSM customers who used Mandiri Syariah Mobile (MSM) and selected samples using convient sampling which included non-probability sampling techniques. The type of data in this study is primary data obtained from filling out questionnaire responses from respondents. The results showed that the transfer feature is the feature most needed by MSM users, while the religious feature is the least needed feature. But the unique level of satisfaction with religious features is the highest compared to other features. There was also a significant effect of the efficiency, trust and blessing variables on customer satisfaction of MSM users, while the convenience variable did not show a significant effect. Customer satisfaction also has a significant effect on increasing customer decisions in transacting through MSM.
\end{abstract}

Keywords : Maslahah, Islamic Bank, Mobile Banking. 


\section{PENDAHULUAN}

Memberikan pelayanan yang prima dengan terus melakukan inovasi menjadi hal penting dalam era revolusi industri 4.0 saat ini, termasuk dalam industri perbankan. Dengan merebaknya beragam bentuk teknologi finansial dan kemudahan untuk mengaksesnya, menuntut perbankan syariah untuk inovatif dalam hal produk dan pelayanan agar tidak terdisrupsi oleh usaha-usaha rintisan berbasis teknologi di bidang keuangan. Salah satu upaya yang dilakukan oleh perbankan untuk mengejar kecepatan teknologi finansial adalah dengan menghadirkan mobile banking. Mobile banking adalah fasilitas layanan dalam pemberian kemudahaan akses maupun kecepatan dalam memperoleh informasi terkini dan transaksi finansial secara real time. (Maulana, Iskandar, \& Mailany, 2018)

Dewasa ini, bank telah memanfaatkan teknologi informasi dalam layanan perbankannya dengan meluncurkan media layanan transaksi perbankan berbasis teknologi informasi, yaitu mobile banking (m-banking). Layanan m-banking membuka kesempatan bagi nasabah untuk melakukan transaksi perbankan melalui perangkat headphone atau Personal Data Assistant. (Wardana, 2015)

Salah satu bagian menarik dari mobile banking adalah keragaman fiturfitur yang dimilikinya sebagai upaya bersaing dengan kompetitornya dan juga mengejar perkembangan teknologi finansial keuangan non perbankan. Fiturfitur yang merupakan bagian layanan dan produk perbankan melalui aplikasi mobile banking menjadi salah satu pertimbangan nasabah untuk menggunakan jasa perbankan tersebut atau tidak.

Hasil penelitian Wahyuningsih dan Janah (2018) menyatakan bahwa layanan perbankan berbasis internet dan aplikasi berpengaruh signifikan terhadap kepuasaan nasabah. Maulana, Iskandar dan Mailany (2018) berkesimpulan bahwa kebermanfaatan dari fitur-fitur mobile banking berpengaruh positif terhadap minat penggunaan jasa perbankan.

Bank Syariah Mandiri (BSM) adalah salah satu bank umum syariah (BUS) yang ada di Indonesia. Dikutip dari website resminya didapatkan keterangan "PT Bank Syariah Mandiri secara resmi mulai beroperasi sejak Senin tanggal 25 Rajab $1420 \mathrm{H}$ atau tanggal 1 November 1999. PT. Bank Syariah Mandiri hadir dan tampil dengan harmonisasi idealisme usaha dengan nilai-nilai spiritual. BSM tumbuh sebagai bank yang mampu memadukan keduanya, yang melandasi kegiatan operasionalnya. Harmonisasi idealisme usaha dan nilai-nilai spiritual inilah yang menjadi salah satu keunggulan BSM dalam kiprahnya di perbankan Indonesia. Per Desember 2017 BSM memiliki 737 kantor layanan di seluruh Indonesia, dengan akses lebih dari 196.000 jaringan ATM.” (Bank Mandiri Syariah, 2019)

Sebagai upaya menjawab tantangan perkembangan teknologi digital, melakukan inovasi berupa pelayanan digital yang prima menjadi hal penting. Melakukan inovasi dan layanan yang prima melalui mobile banking merupakan salah satu yang menjadi prioritas dari BSM. Mobile banking di BSM bernama mandiri syariah mobile (MSM). MSM memiliki fitur-fitur yang berbeda dengan yang dimiliki oleh bank konvensional dan juga bank syariah lainnya. Fitur-fitur yang dimiliki oleh MSM bisa dikelompokkan menjadi 4 yaitu: 1) Fitur transfer, 2) Fitur pembayaran, 3) Fitur pembelian dan 4) Fitur religi. Berdasarkan data google play store aplikasi MSM sudah diunduh oleh $1 \mathrm{jt}+$ pengguna. Jumlah ini masih sangat sedikit jika dibandingkan dengan total nasabah BSM, sehingga perlu dilakukan 
upaya dan inovasi untuk meningkatkan pengguna MSM.

\section{TINJAUAN PUSTAKA}

\section{Kepuasan Nasabah Bank Syariah}

Sebagai bank yang operasionalnya menggunakan prinsip-prinsip syariah, BSM perlu mengetahui lebih mendalam mengenai perilaku dan profil nasabahnya. Menurut Misanam et all., (2008), perilaku konsumen muslim dipengaruhi oleh masalah berkah/keberkatan. Lebih lanjut Misanam menjabarkan tentang teori konsumsi dalam Islam sebagai berikut: penentuan dan pengukuran maslahah bagi konsumen: besarnya berkah yang diperoleh berkaitan langsung dengan frekuensi kegiatan konsumsi yang dilakukan. Sebagaimana dipaparkan di atas bahwa dalam maslahah terkandung unsur manfaat dan berkah. Hal ini bisa dituliskan sebagai berikut:

$$
\mathbf{M}=\mathbf{F}+\mathbf{B}
$$

Keterangan: $\mathrm{M}=$ maslahah, $\mathrm{F}=$ manfaat, $\mathrm{B}=$ berkah

Dalam penelitian ini dengan mengacu kepada penentuan dan pengukuran maslahah sesuai yang disampaikan Misanam et all., (2008), maka faktor-faktor yang mempengaruhi kepuasan nasabah pengguna MSM yang akan diteliti meliputi manfaat (kemudahan, efisiensi, kepercayaan) ditambah dengan keberkahan. Faktorfaktor ini diyakini mewakili profil dari nasabah BSM yaitu sebagai Bank Syariah.

Penelitian mengenai faktor-faktor yang mempengaruhi kepuasan nasabah di perbankan sudah pernah beberapa kali dilakukan. Amijaya (2010) melakukan penelitian dengan judul "Pengaruh Persepsi Teknologi Informasi, Kemudahan, Efesiensi dan Fitur Layanan Terhadap Minat Ulang Nasabah Bank Dalam Menggunakan Internet Banking
(Studi Pada Nasabah Bank BCA)". Hasil penelitian memperoleh bukti bahwa persepsi teknologi, kemudahan dalam menggunakan, efesiensi, dan fitur layanan berpengaruh terhadap minat ulang nasabah bank dalam menggunakan internet banking di bank BCA.

Sedangkan Trisetyanto (2013) melakukan penelitian dengan judul "Analisis Pengaruh Trust dan Mutu Ebanking Terhadap Minat Bertransaksi Online Secara Ulang." Penelitian ini menggunakan metode regresi berganda, hasil penelitian menunjukkan bahwa Trust dan mutu e-banking secara parsial berpengaruh positif dan signifikan terhadap minat bertransaksi ulang secara online nasabah BNI di Semarang.

Perbedaan penelitian ini terkait dengan kepuasan konsumen dengan penelitian sebelumnya adalah peneliti memasukkan variabel "keberkahan" sebagai variabel yang diyakini mempengaruhi kepuasan pengguna MSM. Hal ini juga untuk menguji kebenaran pendapat dari Misanam et all., (2008) tentang penentuan dan pengukuran Maslahah bagi konsumen. Jadi faktorfaktor yang diyakini mempunyai pengaruh positif dan signifikan terhadap kepuasan nasabah mobile banking bank syariah adalah; (1) Kemudahan, (2) Efisiensi, (3) Keyakinan dan (4) Keberkahan. Faktor keberkahan yang menjadikan pembeda antara nasabah bank syariah dengan bank konvensional.

\section{Keputusan Bertransaksi}

Menurut Kotler and Armstrong (2010), dalam melakukan keputusan pembelian, konsumen akan melalui tahap pencarian informasi. Apabila sumber informasi menyatakan puas, maka akan menjadi rekomendasi positif untuk konsumen baru melakukan keputusan pembelian terhadap produk yang sama, sehingga kepuasan pelanggan 
berpengaruh terhadap keputusan pembelian.

$\begin{array}{ccc}\text { Kotler } & \text { dan Keller (2007) } \\ \text { berpendapat } & \text { bahwa } & \text { tahap-tahap }\end{array}$ pengambilan keputusan yaitu pengenalan kebutuhan, pencarian informasi, evaluasi alternatif, keputusan pembelian, perilaku setelah pembelian.

Pendapat Kotler and Armstrong sesuai dengan hasil penelitian dari Rahmat Hidayat dalam Lam (2017) yang juga mendukung penelitian ini yang menyimpulkan bahwa kepuasan pelanggan berpengaruh positif terhadap keputusan pembelian.

Pendapat Kotler dan Armstrong juga sudah diteliti oleh Lam (2017) yang menghasilkan kesimpulan bahwa terdapat pengaruh positif dan signifikan kepuasan pelanggan terhadap keputusan pembelian yang dimediasi word of mouth.

Diambil dari pendapat Kotler di atas maka dalam penelitian ini akan digali informasi mengenai tahap-tahap pengambilan keputusan pengguna MSM yang meliputi; (1) Pengenalan kebutuhan, (2) Pencarian informasi, (3) Evaluasi alternatif, (4) Keputusan pembelian, (5) Perilaku setelah pembelian. Apabila sumber informasi menyatakan puas, maka akan menjadi rekomendasi positif nasabah untuk melakukan keputusan pembelian terhadap produk, dalam hal ini adalah melakukan transaksi melalui MSM.

\section{METODE PENELITIAN}

Penelitian ini adalah penelitian kuantitatif yang menggunakan analisis deskriptif dan analisis structural equation model (SEM). Populasi dalam penelitian ini adalah nasabah BSM yang menggunakan MSM. Teknik pemilihan sampel menggunakan convient sampling yang termasuk dalam teknik sampling non-probability sampling. Convient sampling adalah pengambilan sampel didasarkan pada ketersediaan elemen dan kemudahan untuk didapatkannya. Jumlah sampel pada penelitian ini didasarkan oleh aturan pengumpulan data. Untuk melihat hubungan variabel dilakukan dengan menggunakan kuesioner five point likert scale, (1) Sangat Tidak Setuju, sampai (5) Sangat Setuju.

Jenis data pada penelitian ini yaitu data primer yang diperoleh dari hasil pengisian kuesioner tanggapan responden. Responden diminta untuk menentukan pilihan jawaban masing-masing pertanyaan yang telah disediakan. Untuk memudahkan teknik pengumpulan data pada penelitian ini digunakan Google form yang di isi oleh nasabah BSM yang menggunakan MSM.

Pengolahan data penelitian ini menggunakan analisis deskriptif dan analisis Structural Equation Model (SEM) dengan pendekatan Partial Least Square (PLS) menggunakan software statistic Smart PLS. Analisis deskriptif adalah cara mengumpulkan data dengan cara disusun kemudian diolah lalu dianalisis sehingga menghasilkan gambaran masalah yang ada. (Sugiyono, 2014)

Menurut Ghozali (2014), Structural Equation Model (SEM) merupakan teknik analisis statistic multivariate untuk menguji adanya suatu pengaruh secara langsung maupun tidak langsung yang kompleks baik searah maupun tidak sehingga menghasilkan gambaran menyeluruh mengenai model. SEM dengan pendekatan PLS memiliki fleksibilitas tinggi bagi penelitian untuk menghubungkan antara teori dengan data. 


\section{Gambar 1. Kerangka Penelitian Path Model SEM PLS}

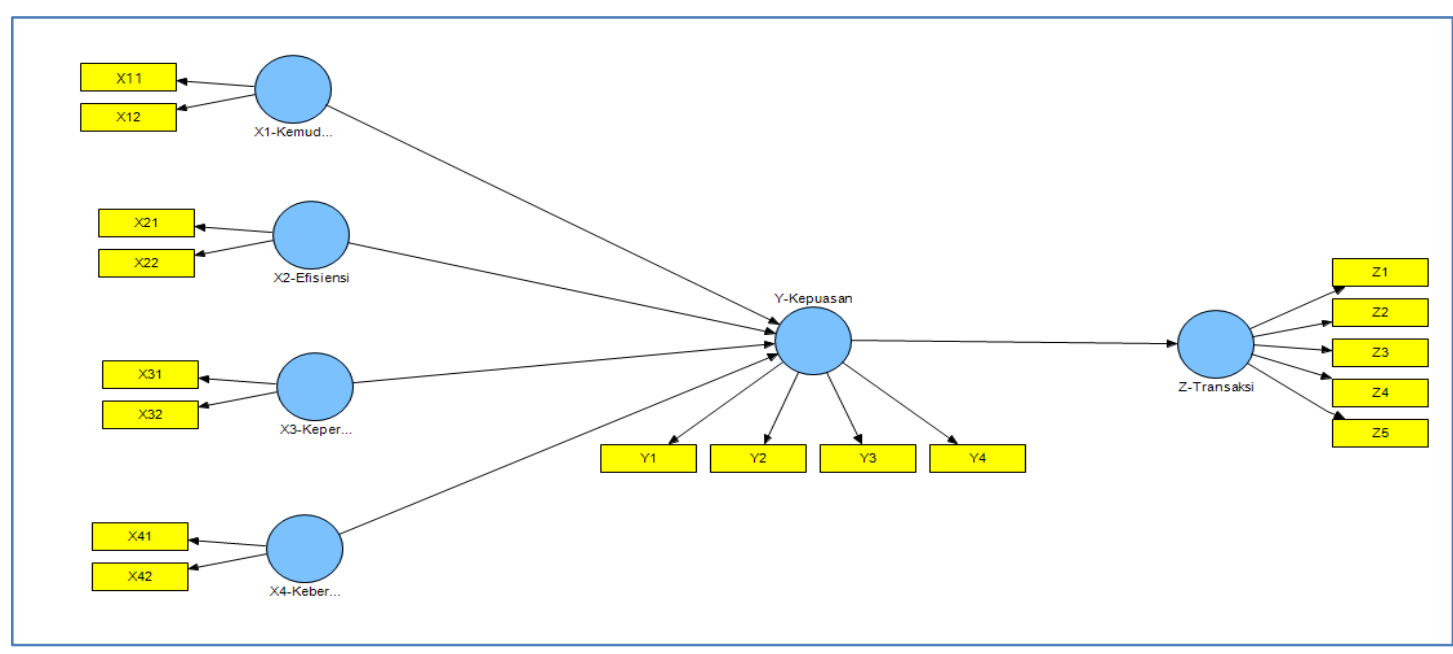

Sumber: Perancangan Model Penelitian (2019)

Dari gambar diatas mengenai kerangka penelitian path model SEM PLS diatas, dapat dijelaskan keterangan variabel laten beserta variabel manifestnya sebagai berikut:

1) Variabel laten eksogen Pengaruh Kemudahan (X1) memiliki dua variabel manifest (indikator) yaitu X11 dan X22.

2) Variabel laten eksogen Pengaruh Efisiensi (X2) memiliki dua variabel manifest (indikator) yaitu X21 dan $\mathrm{X} 22$.

3) Variabel laten eksogen Pengaruh Kepercayaan (X3) memiliki dua variabel manifest (indikator) yaitu X31 dan X32.
4) Variabel laten eksogen Pengaruh Keberkahan (X4) memiliki dua variabel manifest (indikator) yaitu X41 dan X42.

5) Variabel laten eksogen Kepuasan Nasabah (Y) memiliki empat variabel manifest (indikator) yaitu Y1, Y2, Y3, dan Y4.

6) Variabel laten eksogen Peningkatan Transaksi (Z) memiliki lima variabel manifest (indikator) yaitu Z1, Z2, Z3, Z4 dan Z5.

\section{HASIL DAN PEMBAHASAN}

\section{Kepuasan Fitur MSM}

\section{Tabel 1. Tingkat Kepuasan Fitur MSM}

\begin{tabular}{cll}
\hline No. & \multicolumn{1}{c}{ Fitur } & \multicolumn{1}{c}{ Poin } \\
\hline 1 & Religi & 4,44 \\
\hline 2 & Transfer & 4,36 \\
\hline 3 & Pembelian & 4,33 \\
\hline 4 & Pembayaran & 4,17 \\
\hline \multicolumn{2}{l}{ Rata-rata } & 4,33
\end{tabular}

Sumber: Output data diolah (2019)

Keterangan poin dari tabel 1 diatas adalah: 1 (sangat tidak puas), 2(tidak puas), 3 (netral), 4 (puas), 5 (sangat puas).
Dari tabel di atas dapat dijelaskan bahwa rata-rata tingkat kepuasan pengguna MSM adalah 4.33 poin (puas) dengan tingkat 
kepuasan paling tinggi adalah pada fitur religi. Ini menunjukkan bahwa rata-rata pengguna puas dengan fitur-fitur yang ada dengan yang paling memiliki tingkat kepuasan tertinggi adalah fitur religi.

Evaluasi Model Pengukuran (Outer ModeI)

Evaluasi model pengukuran terdiri dari tiga tahap yaitu uji validitas konvergen, uji validitas diskriminan dan uji reliabilitas komposit.

\section{- Uji Validitas Konvergen}

Pengujian validitas untuk indikator reflektif dapat dilakukan dengan menggunakan korelasi antara skor indikator dengan skor konstruknya. Pengukuran dengan indikator reflektif menunjukan terdapat perubahan pada suatu indikator dalam suatu konstruk apabila indikator lain pada konstruk yang sama berubah. Berikut hasil perhitungan menggunakan program komputer smart PLS 2.0:

Tabel 2. Output Result for Outer Loading

\begin{tabular}{|c|c|c|c|c|c|c|}
\hline & $\mathrm{X} 1$ & $\mathrm{X} 2$ & $\mathrm{X} 3$ & $\mathrm{X} 4$ & $\mathrm{Y}$ & Z \\
\hline X11 & 0,949935 & & & & & \\
\hline $\mathrm{X} 12$ & 0,951326 & & & & & \\
\hline $\mathrm{X} 21$ & & 0,922983 & & & & \\
\hline $\mathrm{X} 22$ & & 0,891494 & & & & \\
\hline $\mathrm{X} 31$ & & & 0,945503 & & & \\
\hline X32 & & & 0,943471 & & & \\
\hline $\mathrm{X} 41$ & & & & 0,908312 & & \\
\hline $\mathrm{X} 42$ & & & & 0,900247 & & \\
\hline Y1 & & & & & 0,867386 & \\
\hline Y2 & & & & & 0,879975 & \\
\hline Y3 & & & & & 0,855891 & \\
\hline Y4 & & & & & 0,842689 & \\
\hline $\mathrm{Z1}$ & & & & & & 0,881373 \\
\hline $\mathrm{Z} 2$ & & & & & & 0,865723 \\
\hline $\mathrm{Z3}$ & & & & & & 0,873339 \\
\hline $\mathrm{Z4}$ & & & & & & 0,907208 \\
\hline Z5 & & & & & & 0,892633 \\
\hline
\end{tabular}

Sumber: Data data diolah (2019)

Menurut Chin dalam Ghozali (2012), suatu kolerasi dapat dikatakan memenuhi validitas konvergen apabila memiliki nilai loading sebesar lebih besar dari 0,5. Output menunjukan bahwa loading faktor memberikan nilai di atas nilai yang disarankan yaitu sebesar 0,5. Sehingga indikator-indikator yang dipergunakan dalam penelitian ini telah memenuhi validitas konvergen (convergent validity). 
Tabel 3. Output AVE (Average Variance Extracted) \& Communality

\begin{tabular}{lll}
\hline & AVE & Communality \\
\hline X1 & 0,903699 & 0,903699 \\
\hline X2 & 0,82333 & 0,82333 \\
\hline X3 & 0,892056 & 0,892056 \\
\hline X4 & 0,817738 & 0,817738 \\
\hline Y & 0,742347 & 0,742347 \\
\hline Z & 0,781767 & 0,781767
\end{tabular}

Sumber: Output data diolah (2019)

Nilai AVE yang diharapkan adalah indikator-indikator yang dipergunakan $>0,5$. Output menunjukan bahwa tabel dalam penelitian ini telah memenuhi diatas memberikan nilai AVE di atas nilai validitas konvergen (convergent validity).

yang disarankan yaitu sebesar 0,5. Sehingga indikator-indikator yang dipergunakan dalam penelitian ini telah memenuhi validitas konvergen (convergent validity).

Nilai Communality yang diharapkan adalah $>0,5$. Output menunjukan bahwa tabel diatas memberikan nilai AVE di atas nilai yang disarankan yaitu sebesar 0,5. Sehingga

- Uji Validitas Diskriminan

Pada indikator reflektif perlu dilakukan pengujian validitas diskriminan (discriminant validity) dengan membandingkan nilai pada tabel cross loading. Suatu indikator dinyatakan valid jika mempunyai nilai loading factor tertinggi kepada konstruk yang dituju dibandingkan nilai loading factor kepada konstruk lain.

Tabel 4. Output Cross Loading

\begin{tabular}{ccccccc}
\hline & $\mathrm{X} 1$ & $\mathrm{X} 2$ & $\mathrm{X} 3$ & $\mathrm{X} 4$ & $\mathrm{Y}$ & $\mathrm{Z}$ \\
\hline $\mathrm{X} 11$ & 0,949935 & 0,646077 & 0,692219 & 0,556974 & 0,587463 & 0,703729 \\
\hline $\mathrm{X} 12$ & 0,951326 & 0,620668 & 0,67918 & 0,552313 & 0,595583 & 0,69405 \\
\hline $\mathrm{X} 21$ & 0,594307 & 0,922983 & 0,634168 & 0,536286 & 0,633356 & 0,662196 \\
\hline $\mathrm{X} 22$ & 0,618088 & 0,891494 & 0,620383 & 0,497247 & 0,538022 & 0,63807 \\
\hline $\mathrm{X} 31$ & 0,690502 & 0,621868 & 0,945503 & 0,527303 & 0,629574 & 0,722275 \\
\hline $\mathrm{X} 32$ & 0,671786 & 0,684081 & 0,943471 & 0,55561 & 0,618478 & 0,681868 \\
\hline $\mathrm{X} 41$ & 0,505879 & 0,510074 & 0,467419 & 0,908312 & 0,636076 & 0,585843 \\
\hline $\mathrm{X} 42$ & 0,550268 & 0,522131 & 0,571315 & 0,900247 & 0,611112 & 0,636664 \\
\hline $\mathrm{Y} 1$ & 0,573427 & 0,60397 & 0,614679 & 0,58515 & 0,867386 & 0,73324 \\
\hline $\mathrm{Y} 2$ & 0,486344 & 0,540652 & 0,550698 & 0,556833 & 0,879975 & 0,710602 \\
\hline $\mathrm{Y} 3$ & 0,561329 & 0,543883 & 0,575995 & 0,52267 & 0,855891 & 0,731378 \\
\hline $\mathrm{Y} 4$ & 0,520878 & 0,545459 & 0,533975 & 0,708118 & 0,842689 & 0,704176 \\
\hline $\mathrm{Z1}$ & 0,61205 & 0,636718 & 0,65316 & 0,592743 & 0,805791 & 0,881373 \\
\hline $\mathrm{Z} 2$ & 0,611267 & 0,644868 & 0,624845 & 0,643551 & 0,767902 & 0,865723 \\
\hline $\mathrm{Z3}$ & 0,607372 & 0,58398 & 0,627505 & 0,522582 & 0,701715 & 0,873339 \\
\hline $\mathrm{Z4}$ & 0,716419 & 0,658862 & 0,696275 & 0,612638 & 0,692892 & 0,907208 \\
\hline & & & & & & \\
\hline
\end{tabular}




\begin{tabular}{ccccccc}
\hline Z5 & 0,710017 & 0,640523 & 0,686825 & 0,608379 & 0,711428 & 0,892633 \\
\hline \multicolumn{6}{c}{ Sumber: Output data diolah (2019) }
\end{tabular}

Dari tabel di atas dapat dijelaskan bahwa nilai loading factor masing-masing indikator terhadap konstruk yang dituju lebih tinggi dibandingkan nilai loading factor kepada konstruk lain sehingga indikator-indikator yang ada dinyatakan valid.
- Uji Reliabilitas

Sarwono dan Narimawati (2015) menyatakan bahwa suatu variabel laten dapat dikatakan mempunyai realibilitas yang baik apabila nilai composite reliability lebih besar dari 0,7 dan nilai Cronbach's alpha lebih besar dari 0,7.

Tabel 5. Output Cronbachs Alpha \& Composite Reliability

\begin{tabular}{ccc}
\hline & $\begin{array}{c}\text { Cronbachs } \\
\text { Alpha }\end{array}$ & $\begin{array}{c}\text { Composite } \\
\text { Reliability }\end{array}$ \\
\hline $\mathrm{X} 1$ & 0,893441 & 0,949413 \\
\hline $\mathrm{X} 2$ & 0,786768 & 0,90308 \\
\hline $\mathrm{X} 3$ & 0,879004 & 0,942949 \\
\hline $\mathrm{X} 4$ & 0,7772 & 0,89973 \\
\hline $\mathrm{Y}$ & 0,884217 & 0,920139 \\
\hline $\mathrm{Z}$ & 0,930248 & 0,947108 \\
\hline Sumber: Output data diolah $(2019)$
\end{tabular}

Tabel diatas menunjukan bahwa seluruh variabel-variabel laten yang diukur dalam penelitian ini memiliki nilai Cronbach's Alpha dan Composite Reliability yang lebih besar dibandingkan dengan 0,7 sehingga dapat dikatakan bahwa semua variabel laten reliabel.

\section{a) Evaluasi Model Struktural (Inner Model)}

Evaluasi model struktural pada SEM dengan PLS dilakukan dengan melakukan uji $R$-squared $\left(\mathrm{R}^{2}\right)$ dan uji signifikansi melalui estimasi koefisien jalur.

- Pengujian $\mathrm{R}^{2}$

Output untuk nilai $\mathrm{R}^{2}$ menggunakan program komputer smart PLS 2.0 diperoleh:

Tabel 6. Output R Square

\begin{tabular}{cc}
\hline & R Square \\
\hline $\mathrm{X} 1$ & \\
\hline $\mathrm{X} 2$ & \\
\hline $\mathrm{X} 3$ & \\
\hline $\mathrm{X} 4$ & 0,610357 \\
\hline $\mathrm{Y}$ & 0,698576 \\
\hline $\mathrm{Z}$ &
\end{tabular}

Sumber: Output data diolah (2019)

Nilai $R$-squared $\left(\mathrm{R}^{2}\right)$ dipergunakan variabel laten independen tertentu untuk megukur seberapa besar pengaruh terhadap variabel laten dependen. 
Menurut Chin dalam Ghozali (2012), hasil $\mathrm{R}^{2}$ sebesar 0,67 (kuat), 0,33 (moderat) dan 0.19 (lemah). Tabel diatas menunjukkan nilai $\mathrm{R}^{2}$ penelitian ini sebesar 0,612 yang berarti memiliki nilai lebih besar dari 0,33 tetapi kurang dari 0,67. Maka dapat dikatakan pemodelan yang dibentuk dikategorikan sebagai model yang moderat Y dan kuat untuk Z.

- Uji Signifikansi
Uji signifikansi pada model SEM dengan PLS bertujuan untuk mengetahui pengaruh variabel eksogen terhadap variabel endogen. Pengujian hipotesis dengan metode SEM PLS dilakukan dengan cara melakukan proses bootstrapping dengan bantuan program komputer smart PLS 2.0 sehingga diperoleh hubungan pengaruh variabel eksogen terhadap variabel endogen sebagai berikut:

\section{Gambar 2. Hasil Perhitungan Bootstrapping Data Penelitian}

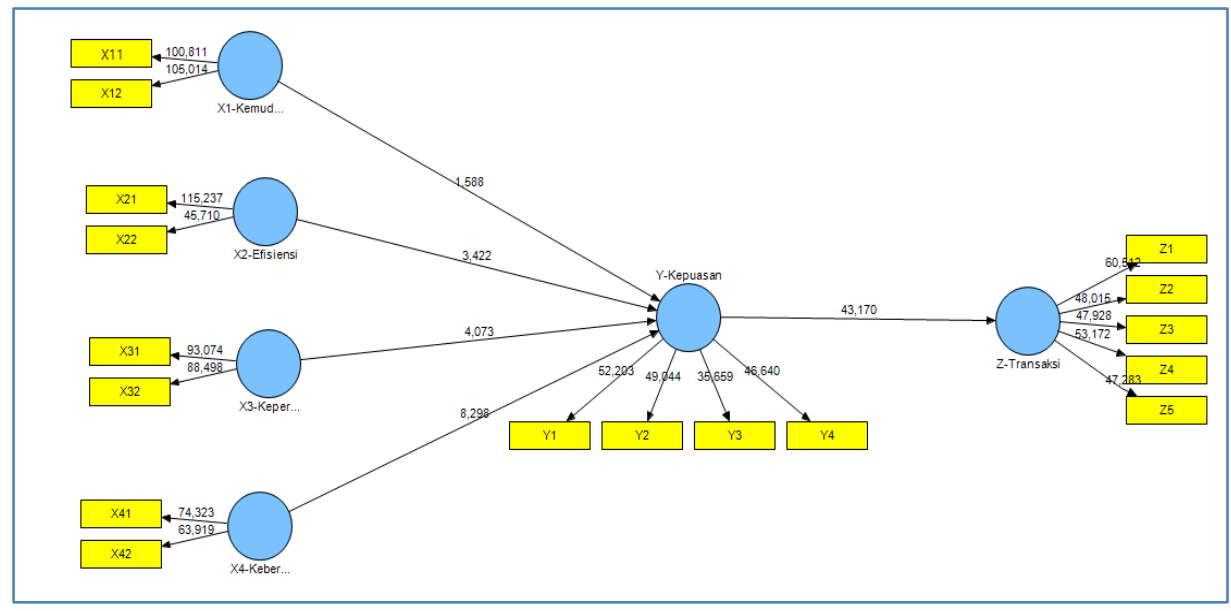

Sumber: Output data diolah (2019)

Tabel 7. Hasil Perhitungan Bootstrapping Data Penelitian

\begin{tabular}{cccccc}
\hline & $\begin{array}{c}\text { Original } \\
\text { Sample } \\
(\mathbf{O})\end{array}$ & $\begin{array}{c}\text { Sample } \\
\text { Mean }(\mathbf{M})\end{array}$ & $\begin{array}{c}\text { Standard } \\
\text { Deviation } \\
(\text { STDEV })\end{array}$ & $\begin{array}{c}\text { Standard } \\
\text { Error } \\
(\text { STERR })\end{array}$ & $\begin{array}{c}\text { T Statistics } \\
(\mid \text { O/STERR })\end{array}$ \\
\hline $\mathrm{X} 1-\mathrm{Y}$ & 0,093998 & 0,093547 & 0,059197 & 0,059197 & 1,587885 \\
\hline $\mathrm{X} 2-\mathrm{Y}$ & 0,20932 & 0,210258 & 0,061169 & 0,061169 & 3,422011 \\
\hline $\mathrm{X} 3-\mathrm{Y}$ & 0,227576 & 0,228373 & 0,055873 & 0,055873 & 4,073067 \\
\hline $\mathrm{X} 4-\mathrm{Y}$ & 0,385116 & 0,384745 & 0,046413 & 0,046413 & 8,297525 \\
\hline $\mathrm{Y}-\mathrm{Z}$ & 0,835809 & 0,837259 & 0,019361 & 0,019361 & 43,170487 \\
\hline
\end{tabular}

Sumber: Output data diolah (2019)

Sebelum dilakukan pengujian hubungan variabel laten ditunjukan hipotesis, diketahui bahwa nilai nilai $\mathrm{T}$ - sebagai berikut:

tabel untuk tingkat kepercayaan sebesar 95\% ( $\alpha$ sebesar $\quad 5 \%)$ dengan 425 Responden adalah sebesar 1,965. Pengujian hipotesis untuk masing-masing a. Pengujian Hipotesis Variabel Pengaruh Kemudahan $\left(\mathrm{X}_{1}\right)$ terhadap Variabel Kepuasan Nasabah (Y). 


$$
\begin{array}{ll}
\mathrm{H}_{01} & \mathrm{X}_{1} \nrightarrow \mathrm{Y} \\
\mathrm{H}_{11} & \mathrm{X}_{1} \longrightarrow \mathrm{Y}
\end{array}
$$

Berdasarkan hasil output tabel 5, T statistik untuk variabel Kemudahan $\left(\mathrm{X}_{1}\right)$ terhadap variabel Kepuasan Nasabah (Y) sebesar 1,587 < T-tabel $(1,965)$. Nilai original sample estimate menunjukan nilai positif sebesar 0,093 yang menunjukan bahwa arah hubungan variabel Pengaruh Kemudahan $\left(\mathrm{X}_{1}\right)$ terhadap variabel Kepuasan Konsumen (Y) adalah positif. T-tabel untuk tingkat kepercayaan sebesar 95\% ( $\alpha$ sebesar 5\%) $\mathrm{H}_{11}$ pada penelitian ditolak. Artinya, dalam penelitian ini variabel laten Pengaruh Kemudahan $\left(\mathrm{X}_{1}\right)$ dengan indikator-indikatornya tidak berpengaruh signifikan terhadap variabel laten Kepuasan Konsumen (Y) dengan indikator-indikatornya.

b. Pengujian Hipotesis Variabel Pengaruh Efisiensi $\left(\mathrm{X}_{2}\right)$ terhadap Variabel Kepuasan Nasabah (Y)

$\begin{array}{ll}\mathrm{H}_{02} & \mathrm{X}_{2} \nrightarrow \mathrm{Y} \\ \mathrm{H}_{12} & \mathrm{X}_{2} \longrightarrow \mathrm{Y}\end{array}$

Berdasarkan hasil output tabel 5, T statistik untuk variabel Efisiensi $\left(\mathrm{X}_{2}\right)$ terhadap variabel Kepuasan Konsumen (Y) sebesar 3,422 > Ttabel $(1,965)$. Nilai original sample estimate menunjukan nilai positif sebesar 0,209 yang menunjukan bahwa arah hubungan variabel Pengaruh Efisiensi $\left(\mathrm{X}_{2}\right)$ terhadap variabel Kepuasan Nasabah (Y) adalah positif. Dengan demikian $\mathrm{H}_{12}$ pada penelitian diterima. Artinya, dalam penelitian ini variabel laten Pengaruh Efisiensi $\left(\mathrm{X}_{2}\right)$ dengan indikator-indikatornya berpengaruh terhadap variabel laten Kepuasan Nasabah (Y) dengan indikatorindikatornya secara signifikan. c. Pengujian Hipotesis Variabel Pengaruh Kepercayaan $\left(\mathrm{X}_{3}\right)$ terhadap Variabel Kepuasan Nasabah (Y)

$$
\begin{array}{ll}
\mathrm{H}_{03} & \mathrm{X}_{3} \nrightarrow \mathrm{Y} \\
\mathrm{H}_{13} & \mathrm{X}_{3} \longrightarrow \mathrm{Y}
\end{array}
$$

Berdasarkan hasil output tabel 5, T statistik untuk variabel Kepercayaan $\left(\mathrm{X}_{2}\right)$ terhadap variabel Kepuasan Nasabah (Y) sebesar 4,073 > T-tabel (1,965). Nilai original sample estimate menunjukan nilai positif sebesar 0,227 yang menunjukan bahwa arah hubungan variabel Pengaruh Kepercayaan $\left(\mathrm{X}_{3}\right)$ terhadap variabel Kepuasan Nasabah (Y) adalah positif. Dengan demikian $\mathrm{H}_{13}$ pada penelitian diterima. Artinya, dalam penelitian ini variabel laten Pengaruh Kepercayaan $\left(X_{3}\right)$ dengan indikator-indikatornya berpengaruh terhadap variabel laten Kepuasan Nasabah (Y) dengan indikatorindikatornya secara signifikan.

d. Pengujian Hipotesis Variabel Pengaruh Keberkahan $\left(\mathrm{X}_{4}\right)$ terhadap Variabel Kepuasan Nasabah (Y)

$\begin{array}{ll}\mathrm{H}_{04} & \mathrm{X}_{4} \nrightarrow \mathrm{Y} \\ \mathrm{H}_{14} & \mathrm{X}_{4} \longrightarrow \mathrm{Y}\end{array}$

Berdasarkan hasil output tabel 5, T statistik untuk variabel Keberkahan $\left(\mathrm{X}_{4}\right)$ terhadap variabel Kepuasan Nasabah (Y) sebesar 8,297 > T-tabel (1,965). Nilai original sample estimate menunjukan nilai positif sebesar 0,385 yang menunjukan bahwa arah hubungan variabel Pengaruh Keberkahan $\left(\mathrm{X}_{4}\right)$ terhadap variabel Kepuasan Nasabah (Y) adalah positif. Dengan demikian $\mathrm{H}_{14}$ pada penelitian diterima. Artinya, dalam penelitian ini variabel laten Pengaruh Keberkahan $\left(\mathrm{X}_{4}\right)$ dengan indikator-indikatornya berpengaruh terhadap variabel laten Kepuasan Nasabah (Y) dengan indikatorindikatornya secara signifikan. 
e. Pengujian Hipotesis Variabel Pengaruh Kepuasan Nasabah (Y) terhadap Variabel Peningkatan Transaksi (Z)

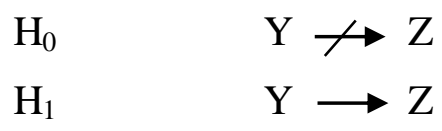

Berdasarkan hasil output Tabel 5, T statistik untuk variabel Kepuasan Nasabah (Y) terhadap variabel Peningkatan Transasi (Z) sebesar 43,170 > T-tabel $(1,965)$. Nilai original sample estimate menunjukan nilai positif sebesar 0,835 yang menunjukan bahwa arah hubungan variabel Pengaruh Kepuasan Nasabah (Y) terhadap variabel Peningkatan Transaksi (Z) adalah positif. Dengan demikian $\mathrm{H}_{1}$ pada penelitian diterima. Artinya, dalam penelitian ini variabel laten Pengaruh Kepuasan Nasabah (Y) dengan indikator-indikatornya berpengaruh terhadap variabel laten Peningkatan Transaksi (Z) dengan indikator-indikatornya secara signifikan.

\section{KESIMPULAN}

Hasil penelitian menunjukkan bahwa pengguna MSM paling banyak adalah nasabah milenial produktif dengan usia 25-35 tahun. Fitur transfer adalah fitur yang paling dibutuhkan oleh nasabah penggun MSM, sedangan fitur religi adalah fitur yang paling tidak dibutuhkan. Tetapi uniknya tingkat kepuasan terhadap fitur religi tercatat paling tinggi dibandingkan dengan fitur-fitur lainnya. Hasil penelitian juga menunjukkan adanya pengaruh signifikan dari variabel efisiensi, kepercayaan (trust) dan keberkahan terhadap kepuasan nasabah pengguna MSM, sedangkan untuk variabel kemudahan tidak menunjukkan pengaruh yang signifikan. Hasil penelitian ini secara bersama-sama menunjukkan bahwa adanya pengaruh yang positif dan signifikan dari aspek maslahah (manfaat dan keberkahan) terhadap kepuasan nasabah pengguna MSM. Kepuasan nasabah tersebut juga berpengaruh signifikan terhadap peningkatan keputusan nasabah dalam bertransaksi melalui MSM dan yang menarik dari hasil penelitian ini adalah tingginya tingkat kepuasan nasabah terhadap fitur religi pada MSM. Ini menunjukkan bahwa hadirnya fitur religi walaupun merupakan fitur yang paling tidak dibutuhkan oleh nasabah pengguna MSM ternyata mampu memberikan kepuasan terhadap nasabah. Namun demikian alangkah lebih baik lagi apabila fitur-fitur utama yang lebih dibutuhkan oleh pengguna MSM untuk bisa lebih ditingkatkan lagi layanannya sehingga nasabah semakin puas dengan layanan fitur-fitur yang ada di MSM.

\section{DAFTAR PUSTAKA}

Amijaya, G. 2010. Pengaruh Persepsi Tekhnologi Informasi, Kemudahan Resiko dan Fitur Layanan Terhadap Minat Ulang Nasabah Bank Dalam Menggunakan Internet Banking (Studi Kasus Pada Nasabah Bank $B C A$ ). Skripsi Jurusan Manajemen, Fakultas Ekonomi - Universitas Diponegoro.

Bank Mandiri Syariah. 2019. Company Profile Bank Mandiri Syariah. Retrieved on August, 2019 from : https://www.mandirisyariah.co.id/te ntang-kami.

Ghozali, I. 2012. Aplikasi Analisi Multivariate dengan Program IBM SPSS 20. Badan Penerbit Universitas Diponegoro. Semarang.

Ghozali, I. 2014. Structural Equation Modelling (SEM) Metode Alternatif dengan Partial Least Square. Penerbit Universitas Diponegoro. Semarang.

Kotler, P., \& Armstrong, G. 2010. Principle of Marketing 13th edition. Pearson Education Inc. New Jersey. 
Kotler, P., \& Keller, K. L. 2007. Manajemen Pemasaran. Edisi 12. Jilid Pertama dan Kedua. PT. Indeks. Jakarta.

Lam, A. E. 2017. Pengaruh Kepuasan Pelanggan Terhadap Keputusan Pembelian Yang Dimediasi Oleh Word of Mouth (Studi Kasus Pada Konsumen Dunkin Donuts di Yogyakarta. Universitas Negeri Yogyakarta. Yogyakarta.

Maulana, R., Iskandar, I., \& Mailany, M. 2018. Pengaruh Penggunaan Mobile Banking Terhadap Minat Nasabah Dalam Bertransaksi Menggunakan Model Penerimaan Tekhnologi. Cyberspace Journal, 2(2), 146-155.

Misanam, M., Suseno, P., \& Hendriento, M. 2008. Ekonomi Islam. LP3EI UII dan Bank Indonesia. Yogyakarta.

Sarwono, J., \& Narimawati, U. 2015. Membuat Skripsi, Tesis dan Disertasi dengan Partial Last Square SEM (PLS-SEM). Penerbit ANDI. Yogyakarta.

Sugiyono. 2014. Metode Penelitian Kuantitatif dan Kualitatif dan $R \& D$. Alfabet. Bandung.

Trisetyanto, T. 2013. Analisis Pengaruh Trust dan Mutu E-Banking Terhadap Minat Bertransaksi Ulang Secara Online (Studi Kasus Nasabah BNI Semarang). Skripsi Jurusan Manajemen Fakultas Ekonomi Universitas Diponegoro.

Wahyuningsih, N., \& Janah, N. 2018. Faktor-Faktor Yang Mempengaruhi Kepuasan Nasabah Menggunakan Internet Banking pada Bank Muamalat. Jurnal Al Amwal,10(2), 295-314.

Wardana, A. 2015. Pengaruh Kualitas Layanan Mobile Banking (MBanking) Terhadap Kepuasan
Nasabah di Indonesia. Derema Jurnal Manajemen, 10(2), 273-284. 